\title{
Body composition and the level of fitness in 10 to 14-year-old girls in western Hungary: the impact of the new PE curriculum
}

\author{
Zsolt Szakály ${ }^{1}$, Ferenc Ihász ${ }^{1}$, Csaba Konczos ${ }^{1}$, Balázs Fügedi², József Bognár ${ }^{3}$ \\ ${ }^{1}$ Szechenyi István University, Faculty of Apáczai Csere János, Györ, Hungary; ${ }^{2}$ University of West Hungary, Savaria \\ Campus, Szombathely, Hungary; ${ }^{3}$ University of Physical Education, Budapest, Hungary
}

\section{Summary}

Study aim: Over the last two decades, the body fat mass has been increasing and the level of physical fitness has been decreasing in school-aged children. Due to the health-related concerns that have arisen regarding school-aged children, the Hungarian government introduced everyday physical education in 2012. Since girls are more disposed to higher body fat and low fitness levels, the aim of our study was to characterise the physique, body composition and aerobic capacity of 10 to 14 -year-old girls three years after the introduction of the new curriculum with daily PE lessons.

Material and methods: All of the primary schools that were selected to participate in this study serve as partnership schools in the University of West Hungary's teacher training programme $(\mathrm{N}=8)$. The sample included only those upper primary school girls (10 to 14 years of age) who participated in the everyday physical education lesson $(\mathrm{N}=543)$. Standard anthropometric techniques and a $20 \mathrm{~m}$ shuttle run test were selected for the analysis.

Results: An important result of this study was the finding that differences in the body composition features were consistently significant among the age groups. However, there were no differences among the age groups in the results of the $20 \mathrm{~m}$ multistage fitness test, nor in the girls' relative aerobic capacity.

Conclusions: It can be presumed that an unfavourable body composition and poor fitness occur primarily in the prepuberty years. Everyday physical education serves as a good opportunity for shaping the girls' fitness level and body composition, and also for encouraging healthy active living.

Key words: Body composition - 20 m multi-stage fitness test - Daily PE - Aerobic capacity - Girls - Uupper primary school

\section{Introduction}

Both inherited characteristics and environmental determinants have been shown to have strong effects on healthy active living, especially in the first two decades of an individual's life [37]. It is well known that the average height and weight of youth has significantly changed from generation to generation [45]. Such body weight differences are mostly influenced by changes in muscle mass and fat accumulation. There has been an observable body fat mass increase over time in both genders, but the accumulation of body fat is higher and the level of fitness is lower in the female population [1,7]. However, body fat content becomes stable in the postpubescent years, where the acceptable range of the body fat percentage is between $21-25 \%$ in girls of this age period $[19,36]$.

Body composition as a structure, and the operation of the organs, function together to determine fitness and motor performance. The body's structure and functions are especially strongly connected in puberty; therefore, the somatic state can be accurately assessed by measuring performances in fitness and motor tests. Bakonyi [2] found that the somatic development and the motor performances in school-aged children in the 1980s had significantly decreased from 1960. Later, Photiou et al. [31] and Mészáros et al. [23] reported similar trends.

Besides these unfavourable anthropometric changes, the physical fitness and physical performance levels of young people have also been decreasing [8, 31, 39, 40], which is mostly due to modifications in the standard of living, lifestyle changes in our societies and also a lack of physical activity (PA) [17, 21, 30, 38, 43]. The most influential factor in these changes is believed to be the social and contextual environment, foremost including the child's family, friends and school [4].

It is well documented that the development of children is greatly determined by their dietary habits, and also 
by the quality and quantity of the physical activities they engage in $[4,5,7,23,32]$. Unfortunately, the levels of physical activity have not been adequate in the past two decades, and as a consequence, the average body fat content has risen to an alarming $24-26 \%$ in 7 to 18 -year-old Hungarian girls [27, 34].

\section{National Core Curriculum (2012) and healthy active living}

The negative consequences that have been observed in connection with lifestyle changes and living standards are widespread throughout Europe. For school-aged children, body composition and fitness levels have reached an increasingly poor level [6, 9, 11, 42, 44, 48]. As a result of the aforementioned factors and also the major healthrelated concerns that have arisen regarding school-aged children, the Hungarian government introduced everyday physical education in 2012.

According to the National Core Curriculum (2012), Hungarian schools are expected to focus more on establishing a healthy active lifestyle for children through having them participate regularly in different types of developmentally appropriate physical activities. Besides physical skills and exercise, physical education in schools also includes the knowledge, values and functions related to healthy active living. It is also expected that the area of PE will promotes the students' physical, motor, psychological, intellectual, emotional and social development, all of which work together to create healthier individuals and a healthier society.

\section{Purpose of the Study}

Due to the fact that girls are more disposed to higher levels of body fat in their puberty years [7, 46, 48], this study aims to examine the body composition, fitness and aerobic capacity of 10 to 14 -year-old girls, three years after the introduction of the new curriculum with everyday PE lessons.

\section{Material and methods}

\section{Sample}

All of the primary schools that were chosen to participate in this study serve as partnership schools in the University of West Hungary's teacher training programme $(\mathrm{N}=8)$. The sample included only those upper primary school girls (between 10 to 14 years of age) who participated in the everyday physical education lessons throughout the academic years of 2012-2015 ( $\mathrm{N}=543)$. Those students who were not involved in daily PE in this period were exempted from this study.

The study was ethically approved by the University's Ethical Committee. An ethical consent form was signed by all of the students and their parents. The research was based on the anonymity of the participants.

\section{Data collection}

The data collection took place in the spring of 2015, on the premises of each of the schools. At least one of the authors was always present at the data collection.

For the estimations of physique and body composition, standard anthropometric techniques were used. When taking the required body dimensions, the prescriptions of the International Biological Program [47] were followed. Official and authenticated anthropological equipment (a Sieber-Hegner anthropometer and an Inbody 720 body composition analyser) were used for the analysis.

The anthropometric parameters were recorded by two experienced professionals; while the motor performances were assessed by the local PE teachers within one week after the anthropometry data collection. Besides measuring the classic anthropometrical features (height and weight), the body fat percentage and muscle mass percentage were measured and the body mass indexes were calculated.

For the evaluation of endurance, the $20 \mathrm{~m}$ shuttle run test was selected. Based on the test results, the aerobic capacity was also calculated [18].

\section{Data analysis}

First, the descriptive statistics (mean, standard deviation, minimum, maximum and coefficient of variation) were calculated for the whole sample and for every age group. The differences between the successive means were analysed by the $F$-test after a one-way ANOVA. In the case of significant $F$ values, Scheffé's critical differences were also calculated. The age-dependence of the measured variables was calculated with a linear regression. The maximum effect of random errors was determined to be consistently below 5\%. Statistica software for Windows (Version 7.1, StatSoft Inc., Tulsa, OK 74104, USA, 2006) was used for the statistical analyses.

\section{Results}

The descriptive statistics of the students' body height is presented in Table 1. The differences in body height means are significant $(\mathrm{F}=79.88, \mathrm{p}<0.001)$. According to the post-hoc analysis, the differences in height in the different age groups are consistently significant among the age groups. The age coefficient of variation is between 4-6 percent, and the regression constant of the body height is $\mathrm{b}=4.13 \mathrm{~cm} \times$ year $^{-1}$.

The descriptive statistics of the body weight differences are presented in Table 2. The differences in means, with the exception of 13 to 14-year-old girls, are significant $(\mathrm{F}=33.34, \mathrm{p}<0.001)$. Both the coefficients of variation 
Table 1. Body height differences by age groups

\begin{tabular}{ccccc}
\hline Age groups [year] & $\mathrm{N}$ & Mean $[\mathrm{cm}] \pm \mathrm{SD}$ & Range $[\mathrm{cm}]$ & $\mathrm{CV}$ \\
\hline 10 & 105 & $145.66 \pm 8.68$ & $132.00-170.00$ & 5.95 \\
11 & 112 & $151.48 \pm 8.03$ & $133.00-171.00$ & 5.30 \\
12 & 110 & $157.35 \pm 6.66$ & $142.00-171.00$ & 4.23 \\
13 & 102 & $161.04 \pm 9.06$ & $126.00-181.00$ & 5.62 \\
14 & 114 & $161.75 \pm 6.93$ & $142.00-178.00$ & 4.28 \\
F/p & & $79.8800 /<0.001$ & \\
B & & $4.13 \mathrm{~cm} \times$ year $^{-1}$ & \\
\hline
\end{tabular}

$\mathrm{SD}$ - standard deviation; Min - the minimum measured value; Max - the maximum measured value; CV - coefficient of variation.

Table 2. Body weight differences by age groups

\begin{tabular}{ccccc}
\hline Age groups [year] & $\mathrm{N}$ & Mean $[\mathrm{kg}] \pm \mathrm{SD}$ & Range & $\mathrm{CV}$ \\
\hline 10 & 105 & $39.93 \pm 10.3$ & $25.40-79.80$ & 25.80 \\
11 & 112 & $45.28 \pm 11.5$ & $27.30-79.80$ & 25.40 \\
12 & 110 & $50.18 \pm 9.78$ & $30.10-76.40$ & 19.49 \\
13 & 102 & $53.94 \pm 12.6$ & $25.30-101.50$ & 23.36 \\
14 & 114 & $53.91 \pm 9.59$ & $30.80-88.10$ & 17.79 \\
F/p & & $33.3400 /<0.001$ & $3.62 \mathrm{~kg} \times$ year $^{-1}$ & \\
B & & & \\
\hline
\end{tabular}

$\mathrm{SD}$ - standard deviation; Min - the minimum measured value; Max - the maximum measured value; CV - coefficient of variation.

and the standard deviations are high. The coefficient of variation is 25.80 percent for the group of 10 -year-old girls, which is the most heterogeneous group in the sample. In the other age groups, the coefficient of variation is between 18-25 percent. The regression constant of the age-dependent body weight is $b=3.62 \mathrm{~kg} \times$ year $^{-1}$.

The differences in the BMI indexes are also significant $(\mathrm{F}=6.142, \mathrm{p}<0.001)$, but there are no differences among the successive age groups. As a result of the large variations in body weight, the standard deviations are also large and the coefficient of variation ranges between 16-20 percent. The regression constant of the BMI is $\mathrm{b}=0.50 \mathrm{~kg} \times$ year $^{-1}$.

For the characterisation of the body composition, relative body fat content and relative muscle mass were used. Table 4 shows these values and the differences in the

Table 3. Body mass index differences by age groups

\begin{tabular}{ccccc}
\hline Age groups [year] & $\mathrm{N}$ & Mean $\left[\mathrm{kg} \cdot \mathrm{m}^{-2}\right] \pm \mathrm{SD}$ & Range & $\mathrm{CV}$ \\
\hline 10 & 105 & $18.62 \pm 3.42$ & $13.70-33.37$ & 18.35 \\
11 & 112 & $19.55 \pm 3.95$ & $13.70-33.40$ & 20.20 \\
12 & 110 & $20.16 \pm 3.19$ & $13.74-28.77$ & 15.81 \\
13 & 102 & $20.69 \pm 3.88$ & $15.90-36.79$ & 18.71 \\
14 & 114 & $20.59 \pm 3.34$ & $15.15-32.56$ & 16.24 \\
F/p & \multicolumn{2}{c}{$6.1420 /<0.001$} & $0.50 \mathrm{~kg} \times$ year $^{-1}$ \\
B & \multicolumn{2}{c}{} \\
\hline
\end{tabular}

$\mathrm{SD}$ - standard deviation; Min - the minimum measured value; Max - the maximum measured value; CV - coefficient of variation. 
Table 4. Body fat percentage differences by age groups

\begin{tabular}{ccccc}
\hline Age groups [year] & $\mathrm{N}$ & Mean [\%] \pm SD & Range & CV \\
\hline 10 & 105 & $21.36 \pm 9.75$ & $5.00-39.00$ & 45.66 \\
11 & 112 & $21.77 \pm 9.74$ & $5.10-38.60$ & 44.72 \\
12 & 110 & $19.98 \pm 7.55$ & $6.10-36.50$ & 37.80 \\
13 & 102 & $22.32 \pm 7.73$ & $11.42-40.70$ & 34.63 \\
14 & 114 & $23.22 \pm 7.56$ & $9.60-38.10$ & 32.55 \\
F/p & & \multicolumn{2}{c}{$2.2040 /=0.0674$} & NS \\
B & & \multicolumn{2}{c}{} \\
\hline
\end{tabular}

$\mathrm{SD}$ - standard deviation; Min - the minimum measured value; Max - the maximum measured value; CV - coefficient of variation.

Table 5. Muscle mass percentage differences by groups

\begin{tabular}{ccccc}
\hline Age groups [year] & $\mathrm{N}$ & Mean [\%] \pm SD & Range & CV \\
\hline 10 & 105 & $36.12 \pm 5.72$ & $17.77-44.25$ & 15.84 \\
11 & 112 & $35.05 \pm 5.63$ & $16.92-43.96$ & 16.07 \\
12 & 110 & $36.21 \pm 4.23$ & $21.47-43.84$ & 11.68 \\
13 & 102 & $36.19 \pm 4.02$ & $22.18-41.04$ & 11.12 \\
14 & 114 & $36.99 \pm 3.70$ & $25.43-42.91$ & 10.00 \\
F/p & & \multicolumn{2}{c}{$2.4093 /=0.0483$} & $0.29 \% \times$ year $^{-1}$ \\
B & & \multicolumn{2}{c}{} \\
\hline
\end{tabular}

$\mathrm{SD}$ - standard deviation; Min - the minimum measured value; Max - the maximum measured value; CV - coefficient of variation.

Table 6. Differences in $20 \mathrm{~m}$ multi-stage fitness test results by age groups

\begin{tabular}{ccccc}
\hline Age groups [year] & $\mathrm{N}$ & Mean [shuttles] \pm SD & Range & CV \\
\hline 10 & 105 & $40.20 \pm 10.26$ & $25.00-51.00$ & 25.52 \\
11 & 112 & $39.75 \pm 9.17$ & $28.00-48.00$ & 23.06 \\
12 & 110 & $41.25 \pm 12.82$ & $12.00-53.00$ & 31,07 \\
13 & 102 & $38.76 \pm 18.06$ & $16.00-86.00$ & 46.59 \\
14 & 114 & $47.23 \pm 20.27$ & & 42.91 \\
F/p & & \multicolumn{2}{c}{$1.7167 /=0.1777$} & \\
B & & NS & \\
\hline
\end{tabular}

$\mathrm{SD}$ - standard deviation; Min - the minimum measured value; Max - the maximum measured value; CV - coefficient of variation.

relative fat content in the different age groups. The differences in means are not significant $(\mathrm{F}=2.204, \mathrm{p}=0.0674)$. However, the differences in the values and the standard deviations are high in every age group. The coefficient of variation ranges between $32-46$ percent.

The differences in the relative muscle mass are significant, but there are no differences among the successive age groups $(\mathrm{F}=2.409, \mathrm{p}=0.0483)$ (Table 5). According to a post-hoc analysis, there are significant differences between the 11-year-old and 14-year-old girls. Also, the means and the value differences are widespread in the various age groups. The coefficient of variance ranges between 10-16 percent, and the age-dependent regression constant of the relative muscle mass is $0.29 \% \times$ year $^{-1}$ 
Table 7. Relative aerobic capacity differences by age groups

\begin{tabular}{ccccc}
\hline Age groups [year] & $\mathrm{N}$ & Mean $\left[\mathrm{ml} \times \mathrm{min}^{-1} \times \mathrm{kg}^{-1}\right] \pm \mathrm{SD}$ & Range & $\mathrm{CV}$ \\
\hline 10 & 105 & $44.12 \pm 3.46$ & $39.12-46.61$ & 7.84 \\
11 & 112 & $43.97 \pm 3.36$ & $36.16-47.38$ & 7.64 \\
12 & 110 & $41.48 \pm 3.78$ & $33.89-49.24$ & 9.11 \\
13 & 102 & $41.88 \pm 4.61$ & $33.29-49.00$ & 11.00 \\
14 & 114 & $41.97 \pm 5.50$ & $33.44-50.69$ & 13.10 \\
$\mathrm{~F} / \mathrm{p}$ & \multicolumn{2}{c}{$0.5316 /<0.6630$} \\
$\mathrm{BS}$ & $\mathrm{N}$ & \\
$\mathrm{B}$ & & \multicolumn{2}{c}{} \\
\hline
\end{tabular}

$\mathrm{SD}$ - standard deviation; Min - the minimum measured value; Max - the maximum measured value; CV - coefficient of variation.

The $20 \mathrm{~m}$ shuttle run test was utilised to characterise the students' endurance performance. The differences in the $20 \mathrm{~m}$ shuttle run means are not significant $(\mathrm{F}=1.716$, $\mathrm{p}=0.1777$ ) (Table 6). It can also be observed that the standard deviations and the differences in the values increase together with the coefficient of variation, which ranges between 23-43 percent. The age-dependent change in the results of the $20 \mathrm{~m}$ shuttle run test is not significant.

There were no differences in the relative aerobic capacity values that were estimated using the shuttle run test results $(\mathrm{F}=0.5316, \mathrm{p}=0.6630)$ (Table 7). The standard deviations gradually increase in the successive age groups. However, the differences in the values are meaningful in every age group. There are no significant differences between the age groups.

\section{Discussion}

One of main results of this study was the finding that the differences in the body composition features were consistently significant among the age groups. The participants in this study were taller and heavier than the population in this region that was tested in the earlier decades, and their height and weight averages exceeded the Hungarian reference values $[10,13,24]$. This kind of secular trend and similar conclusions have been highlighted in earlier studies [7, 26, 46].

A logical explanation for the increase in body weight might be that a greater body weight contains a greater muscle mass. The relative muscle mass mean and the relative body fat were around $22 \%$, which is a similar result to those in previous studies. It can be suggested that both of these components are changing, but the increase in body fat mass seems to be more dominant $[25,35]$. Also, similarly to our results, an earlier study found that the body weight has been constantly increasing and that certain parts of the body weight could not be described by differences in the body dimensions [46].

According to Ng et al. [29], the body composition cannot be reliably estimated on the basis of the body mass index, which includes a person's height and weight. Malina et al. [20] also emphasised that the body mass index can be used for a transformed comparison of the weights of individuals, but does not fully describe their body composition. The critique of Neovius et al. [28] is that the BMI is not a sensible tool for assessing the growing allometries of some factors and the certified age-dependent density changes of some tissues. The researchers who criticise the BMI do not oppose using it, but they call our attention to the fact that the interpretation of the BMI is difficult and is often uncertain. Since considerable reference data is available over an extensive time period, the researchers in this study decided to use the BMI as a follow-up tool.

If we had calculated the BMIs according to the averages published by Eiben et al. [10], we would have found that the BMI values for the age groups in the 1989 sample are smaller. In the present study, the girls' BMI values exceeded the Hungarian references, as did their heights and weights, and were typically around the 75-90 percentiles [13]. Based on childhood BMI data, the prediction of health risks in early adulthood has not been confirmed. However, such predictions are more accurate if we use the BMI values measured in puberty or post-puberty [33].

\section{Fitness and relative aerobic capacity}

The 20-meter shuttle run test has been used as a measurement of fitness in Hungarian schools for only two years. The conversion of the results to the oxygen consumption becomes the foundation of the performance assessment. In this case, there was a possibility to quantify the participants. Legert et al. [18] found a 0.71 correlation coefficient in subjects up to 18 years of age during their validation process, which had a common variance of around 50 percent $\left(r^{2}=0.50\right)$. Thus, we must consider some possible 
problems occurring due to the small common variances when we expand our data.

There were no differences between the age groups in the $20 \mathrm{~m}$ multi-stage fitness test results, nor in the relative aerobic capacity. The $20 \mathrm{~m}$ fitness test ranges were widespread, and as a result, the standard deviations were quite high. One reason for this, besides the major differences in fitness level, might be the level of the students' motivation towards physical activity (PA) and performing well in the testing. The girls' attitude towards PA and towards fitness, and also their fitness level, was generally lower than in the earlier decades $[10,14,15]$.

The relative aerobic capacity values were healthy for untrained adolescents, and were between 40-55 $\mathrm{ml} \cdot \mathrm{min}^{-1} \cdot \mathrm{kg}^{-1}$ [3]. Mészáros [22] has ranked the healthy relative aerobic capacity of 6 to 16 -year-old girls, depending on their ages, as being between $35-52 \mathrm{ml} \cdot \mathrm{min}^{-1} \cdot \mathrm{kg}^{-1}$. The means of the age groups, besides the meaningful standard deviations, were between 41.48-44.12 $\mathrm{ml} \cdot \mathrm{min}^{-1} \cdot \mathrm{kg}^{-1}$; where the difference was significant. The participants' oxygen uptake, according to the Cooper Institute's [12] evaluation, can be categorised as at an excellent level. Hence, there is a need to recognise the effects of daily physical education when we discuss our results, despite the fact that everyday PE has been implemented relatively recently.

The effects of a secular trend are strongly connected with lifestyle changes, and these also affect motoric performances. Mészáros et al. [23] found similar results when they investigated the secular trend in their 25-year survey. They found that the motoric performance of children at the millennium was poorer than it had been 20-25 years earlier.

However, the predicted aerobic capacities in our study were similar to the values measured $20-25$ years ago. Since the shuttle run test results did not change in the 10-14 year age groups and the standard deviations were high, the girls' performances were widespread. It can be presumed that an unfavourable change in height and weight occurs in the prepuberty years; however, the motivation level for performing PE cannot be eliminated as another influential factor.

\section{Everyday $\mathrm{PE}$ as an answer}

School-aged children's spend less time performing vigorous and moderate physical activity, and spend twice as much time with watching TV, as they did 30 years ago [31]. The development of motor skills requires regular and well-planned daily physical activity, which has to be suitable in terms of its tasks, volume and intensity. This aim seems to be well-realised by introducing daily regular physical education in schools.

Protzner et al. [35] did not find any significant differences concerning the relative fat percentage between children who take part in daily PE classes and those who perform physical activity only $2-3$ times per week. However, their study took place only 2 years after the initiation of the new system. For meaningful results in this area, it is probable that more time would be needed following the establishment of everyday PE.

It also has to be emphasised that a school is one of the most important educational sites offering opportunities for shaping a healthy lifestyle and the well-being of children. Daily physical activity can be a useful method for the prevention of health problems and the promotion of fitness, but the society at a macro level and various educational sites at a micro level also have a meaningful role to play in the treatment of this nation-wide problem $[14,15,16,41]$.

A limitation of this study is that through purposeful sampling, it focused only on those schools in partnership with one teacher training programme. For more generalisable results, a greater number of schools should be selected with random sampling.

\section{References}

1. Ailhaud G., H. Hauner (1998) Development of white adipose tissue. In: G.A. Bray, C. Bouvhard, W.P.T. James (eds.): Handbook of obesity. Marcel Decker, New York, pp. 359-378.

2. Bakonyi F. (1984) A testi fejlettségi és a fizikai képességbeli változások a 7-18 éves iskolai tanulóknál. [Biological state and physical abilities change in 7-18 year old schoolchild]. Testnevelés és Sporttudomány, 1-2: 27-36.

3. Bar-Or O. (1983) Pediatric sports medicine for the practitioner. Springer, New York, Berlin, Heidelberg, Tokyo.

4. Bauman A.E., R.S. Reis, J.F. Sallis, J.C. Wells, R.J.F. Loos, B.W. Martin (2012) Correlates of physical activity: Why are some people physically active and others not? The Lancet, 380: 258-271.

5. Beunen G. (2003) Physical growth, maturation and performance. Revista Portuguesa de Ciencias do Desporto, 3: 11-12.

6. Bielicki T. (1986) Physical growth as a measure of economic well-being of populations: The twentieth century. In: F. Falkner, J.M. Tanner (eds.): Human Growth. Vol. 3. Methodology, Ecological, Genetic, and Nutritional Effects on Growth. Plenum Press, New York, pp. 283-305.

7. Bodzsár É.B. (1998) Secular growth changes in Hungary. In: Bodzsár É. B. and C. Susanne (eds.): Secular growth changes in Europe. Eötvös University Press, Budapest, pp. 175-205.

8. Dalton M., A.J. Cameron, P.Z. Zimmet, J.E. Shaw, D. Jolley, D.W. Dunstan, T.A. Welborn and On behalf of the AusDiab steering committee (2003) Waist circumference, waist-hip ratio and body mass index and their correlation 
with cardiovascular disease risk factors in Australian adults. J. Intern. Med., vol. 254, 6: 555-563.

9. Davison K.K., L.L. Birch (2001) Weight status, parent reaction, and self-concept in five-year-old girls. Pediatrics, 107(1): 46-53.

10. Eiben O., E. Pantó, A. Barabás (1989) Adatok GyőrMoson-Sopron megye ifjúságának biológiai fejlettségéhez és fizikai erőnlétéhez. [The biological state and condition of youth in Györ-Moson-Sopron County]. Humanbiologia Budapestinensis, 7. (Suppl.)

11. Guo S.S., W.C. Chumlea, A.F. Roche, R.M. Siervogel (1997) Age-and maturity-related changes in body composition during adolescence into adulthood: The Fels Longitudinal Study. Int. J. Obes., 21: 1167-1175.

12. Heyward V.H. (1998) The Physical Fitness Specialist Certification Manual, The Cooper Institute for Aerobics Research, Dallas TX, revised 1997 printed in Advance Fitness Assessment \& Exercise Prescription, 3rd Edition, pp. 48.

13. Joubert K., S. Darvay, Gy. Gyenis, Ö. Éltető, K. Mag, M. van't Hof, R. Ágfalvi (2006) Az Országos Longitudinális Gyermeknövekedés-vizsgálat eredményei születéstől 18 éves korig I. [The representative longitudinal measurement in Hungary from the birth to 18 ages]. In: K. Jouber (eds.): KSH Népességtudományi Kutató Intézetének Kutatási Jelentések pp. 83.

14. Kiss I., I. Barna, G. Dankovics, T. Daiki (2014) Népegészségügyi prevenció Magyarországon II.: megalapozott módszerekkel, megfelelő információval, valódi szürési eredmények. [The national health prevention with adequate methods, suitable information and authentic check-up results in Hungary]. LAM, 24(1-2): 43-48.

15. Konczos Cs., F. Ihász, Zs. Szakály, A. Huszár (2006) $\mathrm{Az}$ egészségtudatos életvitel is megtanulható? [Can be learned the healthy live?] Magyar Sporttudományi Szemle, 7(4): 20-23.

16. Konczos Cs., Zs. Szakály (2007) Az ifjúság fizikai aktivitásának jellemzői, az életstílus befolyásolása, a fizikai aktivitás tudatos alkalmazása. [Physical activity pattern, lifestyle and conscious using of physical activity]. Magyar Sporttudományi Szemle, 8(2): 39-46.

17. Laki L., M. Nyerges (2000) Sporting habits of youth in Hungary in the Millennium. Kalokagathia, 75th Anniversary Special Issue, 24-35.

18. Leger LA., D. Mercier, C. Gadoury, J. Lambert (1988) The multistage 20 meter shuttle run test for aerobic fitness. J. Sports Sci., 6(2): 93-101.

19. Lohman T.G. (1992) Advances in body composition assessment. Human Kinetics Publishers, Inc., Champaign, Illinois, pp. 26-30.

20. Malina R.M., C. Bouchard, O. Bar-Or (2004) Growth, maturation, and physical activity. Human Kinetics, Champaign, Illinois, pp. 554-556.

21. Marshall S.J., S.J.H. Biddle, T. Gorely, N. Cameron, I. Murdey. (2004) Relationships between media use, body fatness and physical activity in children and youth: a meta-analysis. Int. J. Obes., 28: 1238-1246.

22. Mészáros J. (eds.) (1990) A gyermeksport biológiai alapjai. The biological basis for sport of rising generation. Sport. Budapest, pp. 156-157.

23. Mészáros J., T. Szabó, J. Mohácsi, L.Ch. Pheng, A. Tatár (2002) A motorikus szekuláris trend. The secular trend of physical abilities. Magyar Sporttudományi Szemle, 3: 4-7.

24. Mészáros J., Zs. Mészáros, M. Zsidegh (2011): Leányok testi fejlődése és relatív testzsírtartalma. [Biological development and relative body fat percent in girls]. Magyar Sporttudományi Szemle 12: 57.

25. Mészáros Zs., I. Vajda, J. Mészáros, P. Polydoros, Á. Sziva, P. Osváth, M. Zsidegh (2007) Korai gyermekfejlődés: a szocio-ökonómiai státus hatása. [Socioeconomic influences of somatic and motor development.] Magyar Sporttudományi Szemle, 8: 8-13.

26. Mészáros Zs., J. Mészáros, B.M. Szmodis, P. Pampakas, P. Osváth, E. Völgyi (2008) Primary school child development- issues of socioeconomic status. Kinesiology 40(2): 153-161.

27. Mészáros J., I. Vajda, Zs. Mészáros, A. Photiou, A. Prókai, Á. Sziva (2006) Body fat and running performance changes in prepubertal school girls (1980-2005). Res. Q. Exerc. Sport, 77: 1. A20.

28. Neovius M., Y. Linné, B. Barkeling, S. Rössner (2004) Discrepancies between classification systems of childhood obesity. Obes. Rev., 5: 105-114.

29. Ng N.K., J. Mészáros, A. Farkas (1996/97) Assessment of body composition of physically active male youth. Anthropológiai Közlemények, 38: 93-100.

30. Pearson N., R.E. Braithwaite, S.J.H. Biddle, E.M.F. van Sluijs, A.J. Atkin (2014) Associations between sedentary behaviour and physical activity in children and adolescents: a meta-analysis. Obes. Rev., 15: 666-675.

31. Photiou A., J. Anning, J. Mészáros, I. Vajda, Zs. Mészáros, Á. Sziva, A. Prókai, N. Ng (2008) Lifestyle, body composition and physical fitness changes in Hungarian school boys (1975-2005). Res. Q. Exerc. Sport, 79: 168-173.

32. Post G.B., H.C.G. Kemper, J.W.R. Twisk, (1997) Biological maturation in relation to lifestyle from adolescence into adulthood. In: N. Armstrong, B.J. Kirby, J.R. Welsman (eds.): Children and exercise XIX. Promoting health and well-being. E. and F.N. SPON, London, pp. 57-62.

33. Power C., J.K. Lake, T.J. Cole (1997) Body mass index and height from childhood to adulthood in the 1958 British birth cohort. Am. J. Clin. Nutr., 66: 1094-1101.

34. Prókai A., E. Völgyi, Zs. Mészáros, A. Tatár, M. Zsidegh, M. Uvacsek, I. Vajda, J. Mészáros (2005) Relatív testzsírtartalom és motorikus teljesítmény. [Relative body fat percent and physical performance]. In: A. Mónus, (eds.) IV. Országos Sporttudományi Kongresszus II. MSTT, Budapest, pp. 238-243. 
35. Protzner A., E. Trájer, E. Bosnyák, A. Udvardy, G. Szőts, M. Tóth, M. Szmodis (2015) Iskoláskorúak fizikai aktivitása és testzsírja: a mindennapos testnevelés első hatásvizsgálata. [First study of the effect of everyday physical education in Hungarian students by monitoring physical activity and body composition]. Magyar Sporttudományi Szemle, 16: 15-20.

36. Pucsok J. (2000) A rendszeres fizikai aktivitás hatása a szervezetre. [Influence of the habitual physical activity for the human organism]. www.vitalitas.hu

37. Rankinen T., L. Pérusse, R. Rauramaa, M.A. Rivera, O. Wolfarth, C. Bouchard (2002) The human gene map for performance and health-related fitness phenotype. The 2001 update. Med. Sci. Sports Exerc., 34: 1219-1233.

38. Ross R., I. Janssen, A. Tremblay (2000) Obesity reduction through lifestyle modification. Can. J. Appl. Physiol., 1: 1-18.

39. Rowland T.W. (2003) Effects of body fat on cardiovascular fitness in youth. Revista Portuguesa de Ciencias do Desporto, 3: 18-19.

40. Rowland T.W. (2005) Children's exercise physiology. Human Kinetics Publishers, Inc., Champaign, Illinois.

41. Shephard R.J., F. Trudeau (2000) The legacy of physical education: influences on adult lifestyle. Paediatr. Exerc. Sci., 1: 34-50.

42. Stevens J., D.M. Murray, C.D. Baggett, J.P. Elder, T.G. Lohman, L.A. Lytle, D.R. Young (2007) Objectively assessed associations between physical activity and body composition in middle-school girls the trial of activity for adolescent girls. Am. J. Epidemiol., 166(11): 1298-1305.
43. Telama R., X. Yang (2000) Decline of physical activity from youth to young adult-hood in Finland. Med. Sci. Sports Exerc., 9: 1617-1622.

44. Thorkild I., A. Soerensen (1997) Genetic and environmental factors related to the development of obesity in youngsters. In: K. Froberg, O. Lammert, H.ST. Hansen, C.J.R. Blimkie (eds.): Exercise and fitness - benefits and risks. Odense University Press, Odense, pp. 37-48.

45. Tóth G.A., O.G. Eiben (2004) The secular changes of body measurements in Hungary. Humanbiologia Budapestinensis, 28: 7-72.

46. Vajda I. (2008) A motorikus teljesítmények és az antropometriai jellemzők kapcsolata 7-10 éves nem sportoló gyermekeknél. [Relationship between motor performance and anthropometrical characteristics of non-athletic children aged 7-10. PhD. dissertation]. Doktori Értekezés. Semmelweis Egyetem Testnevelési és Sporttudományi Kar. Budapest, pp. 32-37.

47. Weiner J.E.S., J.A. Lourie (eds.) (1969) Human Biology. A Guide to Field Methods. IBP Handbook, No. 9. Blackwell Scientific Publishers, Oxford.

48. Zsákai A., É.B. Bodzsár (2007) The method dependent prevalence of overweight and obesity in children. $\mathrm{Hu}$ manbiologia Budapestinensis, 31: 11-18.

\section{Received 03.03.2016 \\ Accepted 12.07.2016}

(C) University of Physical Education, Warsaw, Poland 